\title{
Bennelong among his people
}

\author{
Keith Vincent Smith
}

Woollarawarre Bennelong (c1764-1813) was the most significant Indigenous man in early Sydney and also, in retrospect, the most misrepresented and underestimated. He was one of the first to face the dilemma of knowing two cultures. In the end he chose his own. Bennelong did not fade into obscurity in the second part of his life after his return from England in 1795. He resumed a traditional Aboriginal lifestyle, regained authority as a leader, remarried and had a son. He died at the age of 50 as a respected elder mourned by his people.

This article is based on a careful examination and unravelling of records compiled by the British officers of the 'First Fleet', whose journals, diaries, language notebooks, official despatches, private letters and printed histories still survive. As Marcia Langton remarked: 'These officers were the first British ethnologists, whatever their purposes and whatever their prejudices. ${ }^{1}{ }^{1}$ Whatever their motives, these observers wrote down what they saw with their own eyes and what they were told by their Indigenous informants, principally Bennelong.

The first section of the article locates Bennelong in relation to his names, kin and country and traces his strategy in brokering alliances among his own people through political marriages for himself and his sisters. This plan succeeded in creating and maintaining a web of kinship ties and relationships that extended his influence and ensured that he remained a clan leader.

Captured in November 1789 on the orders of Arthur Phillip, first governor of the convict colony of New South Wales, Woollarawarre Bennelong soon became a valued informant and go-between. He formed an unlikely friendship with Phillip, who in 1792 took Bennelong and his young kinsman Yemmerrawanne to England.

Five years after his return Bennelong moved from the Sydney Cove settlement and became the leader of a 100-strong clan living along the Parramatta River west of Ryde. He eventually went to live in the orchard of the friendly brewer James Squire.

His kin succeeded him after his death. Bennelong's brother-in-law Harry became chief at Parramatta and his half brother-in-law Bidgee Bidgee was the clan head of the Kissing Point (Ryde) 'tribe' for 20 years.

1 Langton 1993[1977]: 87. 
The second section contests the repeated historical convention that Bennelong was despised by his own people.

Anthropologist Stephen Greenblatt questioned the motives and veracity of travellers and voyagers who wrote books in what Mary Louise Pratt called the 'contact zone' or 'space of colonial encounters'. ${ }^{2}$ Examining the reports of Christopher Columbus (Cristóbal Colón), Greenblatt concluded that 'We can be certain only that European representation of the New World tells us something about the European practice of representation. ${ }^{\prime 3}$ Columbus and others spent little time in the lands they 'discovered' driven by the quest for wonders and riches, whereas the British colonists came to establish a convict settlement in a new country. They were not travellers but settlers.

While the First Fleet outsiders considered themselves more 'civilised' and superior to the Indigenous people, whom they regarded as 'savages' or 'Indians', there was no reason for them not to tell the truth as they saw and understood it.

Historian Inga Clendinnen praised the 'dutiful recording' of David Collins, whose An Account of the English Colony in New South Wales, published in London in 1798 and reprinted in many English journals, was a major influence in the 'European representation' of Aboriginal life and culture. Without Collins, wrote Clendinnen, 'it would be difficult to trace the interactions between Australians [Aboriginal Australians] and British in the years after the Australians decided to "come in" to Sydney Town'. ${ }^{4}$ Collins spent eight years in New South Wales before leaving in August 1796.

The major aim of this paper, then, is to rehabilitate the received image of Bennelong that has for so long been copied from one history to another with no questioning of the secondary sources or interrogation of the primary historical evidence. None of the information in this essay could have been recovered without the original accounts. There would be little Aboriginal history of Sydney's early post-colonial period without them. This methodology, as Peter Watts remarked about Fleeting Encounters, the inaugural exhibition at the Museum of Sydney in 1995 , 'is not from adding new data but from liberating the old'. ${ }^{5}$

\section{Bennelong's kin and country}

Names held layers of meaning to the Indigenous people of the Sydney area. 'Each person has several names, one of which, there is reason to believe is always derived from the first fish or animal, which the child, in accompanying its father

2 Pratt 1992: 6.

3 Greenblatt 1995[1991]: 7.

4 Clendinnen 2003: 54. Extracts from Collins's Account (some with references to 'Ben-nil-long' were reprinted), for example, in The Monthly Review, London, September-December 1798, The British Critic, London, 1798, The European Magazine, London, January 1799, The Annual Register, London, 1798 and The Annual Review1802, London, 1803.

5 Watts 1995: 7. 
to the chace [hunt] or a fishing, may chance to kill', wrote Marine Captain Watkin Tench. ${ }^{6}$ Judge Advocate David Collins observed that it was the custom to name a child once he or she was between one and six months of age. ${ }^{7}$ These first given names, often called totem names, after the Algonkian totam, meaning 'kinsman', linked a child with an emblem from the natural and supernatural worlds that Aboriginal people considered a part of their identity. In most parts of Australia it is forbidden to kill, injure or eat your totem. Male children took another name at initiation, which was seldom divulged to outsiders. Men and women exchanged names with each other and with European settlers, who also gave them nicknames. It was forbidden to speak the name of a recently dead person.

Bennelong had five names, written with many variations in spelling and order by the journal keepers of the First Fleet. A vocabulary kept by Governor Arthur Phillip and his aides gave them as 'Wo-lar-re-barre, Wog-ul-trowe, Bannel-lon, Boinba, Bunde-bunda', Philip Gidley King as 'Bannelon, Wollewarre, Boinba, Bunde-bunda, Wogletrowey' and David Collins as 'Ben-nil-long, Wolar-ra-bar-ray, Wo-gul-trow-e, Boinba, and Bun-de-bun-da' ${ }^{8}$

Bund-bunda meant 'hawk', but the meanings of Bennelong's other names are obscure. ' 'Bennillong told me his name was that of a large fish, but one that I never saw taken', wrote David Collins. ${ }^{10}$ According to Captain John Hunter, Vogle-troo-ye and Vo-la-ra-very 'were names by which some of his particular connections were distinguished, and which he had, upon their death, taken up' ${ }^{11}$

Watkin Tench said Bennelong preferred the name Woollarawarre.

Although I call him only Bannelon, he had besides several appellations; and for a while he chose to be distinguished by that of Wo-lar-a-wàr-ee. Again, as a mark of affection and respect to the governor, he conferred on him the name of Wolarawaree, and sometimes called him Been-èn-a (father), adopting to himself the name of governor. This interchange of names, we found is a constant symbol of friendship among them. ${ }^{12}$

Phillip called Bennelong Doorow (son) and Bennelong named both Judge Advocate David Collins and Commissary John Palmer Babunna (brother).

6 Tench 1793: 202.

7 Collins 1975[1798-1802] I: 465.

8 Anon c1791, 'Vocabulary of the language of N.S. Wales in the neighbourhood of Sydney (Native and English, but not alphabetical)', Notebook C, School of Oriental and African Studies, University of London, MS 41645 (c): 41.13, ['Governors' Vocabulary' - hereafter GV c1791]: 57.8; King in Hunter 1793: 405; Collins 1975[1798-1802] I: engravings vii.

9 'Bunda - hawk', John Rowley in Ridley 1875: 104.3b; 'hawk - bunda', Troy 1993: 5.28.

10 Collins 1975[1798-1802] I: 465.

11 Hunter 1793: 168.

12 Tench 1793: 35. 
Woollarawarre Bennelong was born about 1764, somewhere on the south shore of the Parramatta River. This was the country of the Wangal. When he died in 1813, Bennelong was buried in Wallumedegal territory on the north side of the river at Ryde.

Based on surviving vocabularies and references, the original inhabitants of the Sydney coast called themselves Eora (yura), simply meaning 'People'. In his published vocabulary (1798), Collins listed 'Eo-ra - The name common for the natives' and wrote elsewhere, 'I then asked [Bennelong] where the black men (or Eora) came from.' ${ }^{13}$ The Eora were united by strong ties of kinship and a common language, spoken in the area from the Georges River and Botany Bay in the south to Port Jackson (Sydney Harbour), north to Pittwater and west to Parramatta. ${ }^{14}$

Eora clans were named after the places they inhabited, or for a totem that they revered, with the addition of the suffix - gal, which meant a clan or extended family group, which might number from 20 to 60 men, women and children. Clans were exogamous: they took their wives from adjoining clans and came together regularly for ceremonies or to avenge the deaths of family members. Galiang specifically meant the female members of a clan.

Bennelong, wrote Tench, 'willingly communicated information [and] told us all the details of his family economy' ${ }^{15}$ Less than three months after his capture, on 13 February 1790, Phillip passed on the names and locations of eight coastal clans in a dispatch to Lord Sydney at the Home Office in London. ${ }^{16}$ Bennelong also told Phillip that 'one-half of those who inhabit this part of the country' had died from smallpox.

Three Aboriginal clans occupied the saltwater Parramatta River at the time of the English invasion in January 1788: Wangal on the south shore, Wallumedegal to the north and Burramattagal at the source. Bennelong, wrote Collins,

often assured me, that the island Me-mel (called by us Goat Island) close by Sydney Cove was his property; that it was his father's ... He told us of other people who possessed this hereditary property, which they retained undisturbed. ${ }^{17}$

'The South Side of the Harbour from the above-mentioned Cove [adjoining to this settlement] to Rose-Hill, which the natives call Parramatta, the District is called Wann, \& the Tribe Wangal', Arthur Phillip informed Lord Sydney in February $1790 .{ }^{18}$ Philip Gidley King stated that the 'adjoining cove' was

13 Collins 1975[1798-1802] I: 508, 454; 'people or Aboriginal people', Troy 1993: 39.2.

14 Smith 2004: 1-30; Wafer and Lissarrague 2008: 142-145.

15 Tench 1793: 36.

16 Phillip to Sydney, 13 February 1790, Historical Records of Australia [hereafter HRA], vol II: 308.

17 Collins 1975[1798-1802] I: 497. Aboriginal people today say that Bennelong was the custodian of the island.

18 Phillip to Sydney, 13 February 1790, HRA, vol II: 308. 
Long Cove, now Darling Harbour. ${ }^{19}$ In today's geography, Wangal territory began at Memel or Goat Island, rounded the Balmain Peninsula and ran west along the south bank of the Parramatta River, almost to Parramatta, home of the Burramattagal (Eel place clan). The Wallumedegal or Wallamattagal, a name derived from wallumai, the snapper fish, occupied the north shore of the Parramatta River, west of its intersection with the Lane Cove River.

\section{Abduction}

Governor Arthur Phillip had orders from King George III to 'endeavour, by every possible means, to open an intercourse with the natives, and to conciliate their affections, enjoining all subjects to live in amity and kindness with them ${ }^{20}$ No Aboriginal people ventured into the Sydney settlement after February 1788. To comply with his orders, Phillip directed that one or more be seized. On 30 December 1788, a young man named Arabanoo was taken at Manly Cove. He died from smallpox in May 1789 after helping to nurse Nanbarry and Boorong two children who had contracted the disease - through their illness. ${ }^{21}$

The governor wanted another Aboriginal man who could be taught to speak English to act as a go-between and interpreter. At the age of about 25, Bennelong was unwillingly thrust into British history when he and his companion Colebee were abducted from Manly Cove in late November 1789. They were bound with ropes and taken by boat to Sydney Cove. Colebee, chief of the harbour-dwelling Cadigal, escaped on 12 December.

Tench described Bennelong as being about 26 years old 'of good statue, and stoutly made, with a bold intrepid countenance, which bespoke defiance and revenge'. He was wiry and muscular with a flat nose and a bright twinkle in his dark eyes. Captain John Hunter said Bennelong was 'a very good looking young fellow, of a pleasant, lively disposition'. They would find that he was also mercurial, quick to laughter or anger, a clever mimic and a wily and cunning politician.

Bennelong endeavoured to find a place for Governor Phillip and his officers in the traditional kinship system of his people, calling the governor Beanga (Father) and himself Doorow (Son). In his dealings with Phillip, Bennelong received privileges such as extra rations and clothing and valuable items like metal knives, hatchets and fishhooks, in exchange for Aboriginal weapons and artefacts. According to Greenblatt, European voyagers 'believed they could

19 King 2006[1790]: 406.

20 George III to Arthur Phillip, 27 April 1787, Public Record Office [hereafter PRO], CO21/1.

21 For a full account of Bennelong's relationship with Governor Arthur Phillip and his aides until his departure for England in 1792, see Smith 2001. 
communicate with the Indigenous people 'through the giving of gifts', which was not reciprocal. ${ }^{22}$ By contrast, the exchange of gifts between Phillip and his aides and Bennelong and his people was usually reciprocal. ${ }^{23}$

In November 1790, Phillip built Bennelong a brick hut at Tubowgulle, now Bennelong Point. Bennelong told Phillip that when he went to the south shore of Botany Bay in December 1790, 'they danced, and that one of the tribe had sung a song, the subject of which was, his house, the governor, and the white men at Sydney'. The corroboree celebrated a peace agreement with his former enemies the Gweagal, who, he said, 'would not throw any more spears'. He also became friendly with the north shore Cameragal only a few days after asking Phillip to kill them all. ${ }^{24}$ Bennelong's hut was demolished in November 1795, two months after his return from England.

\section{Bennelong's sisters}

According to a writer using the nom de plume 'Atticus', Bennelong's father was Goorah-Goorah and his mother Ga-golh. ${ }^{25}$ In his second language notebook (1791), Marine Lieutenant William Dawes listed the names of Bennelong and his sisters: 'Beneláng . Wariwéar . Karangarang . Wúrrgan . Munánguri' ${ }^{26}$

Bennelong forged political alliances with influential Aboriginal men through the marriages of his sisters Warreeweer (Wariwéar) and Carangarang (Karangarang). Warreeweer married Anganángan or Gnung-a Gnung-a Murremurgan, who adopted the name 'Collins' from Phillip's aide David Collins. ${ }^{27}$ In 1793, while Bennelong was in England, Gnung-a Gnung-a sailed across the Pacific aboard the storeship HMS Daedalus to Norfolk Island, North America and Hawaii.

While her husband was at sea, Warreeweer lived with an Aboriginal man described by Collins as 'a very fine young fellow, who since his coming among us had gone by the name of Wyatt'. A few days after his return, Gnung-a Gnung-a wounded Wyatt and, said Collins, 'the wife became the prize of the victor' ${ }^{28}$

22 Greenblatt 1995: 13.

23 Smith 2001: 147-155 - Chapter 20, 'The skilful game'.

24 Hunter 1793: 493.

25 Sydney Gazette, 29 March 1817: 1c-2b.

26 Dawes 1791, 'Vocabulary of the language of N.S. Wales in the neighbourhood of Sydney. Native and English, by - Dawes', SOAS, Marsden Collection, Notebook B, MS 4165 (b) [hereafter Dawes 1791]: 9.4 .

27 Collins 1975[1798-1802] I: 250; Dawes 1790, 'Grammatical forms of the language of N.S. Wales, in the neighbourhood of Sydney, by - Dawes, in the year 1790', SOAS, Marsden Collection, Notebook A, MS 4165 (a) [hereafter Dawes 1790]: 16.

28 Collins 1975[1798-1802] I: 303; several instances were recorded in which a wife found another partner while her husband was away for some time. William Dawes recorded Mákung as 'Sweetheart or lover' and Mákungáli as 'Husband. Wife', Dawes 1791: 20.7; while Collins translated Mau-gohn-nal-ly, as 'A temporary [wife]', Collins 1975[1798-1802] I: 509; 'marital partner - mau-gohn-nal-lay (a temporary wife)', Troy 1993: 40.20. 
The couple had a female child in 1791, who died the same year. Warreeweer was again pregnant in July 1793 when Gnunga-a Gnung-a left Sydney, but that child also died. ${ }^{29}$

Bennelong's brother-in-law Gnung-a Gnung-a came from the Hawkesbury River or from Broken Bay, north of the river. According to Thomas Campbell, secretary to Governor Lachlan Macquarie, Gnung-a Gnung-a's brother Phillip or 'Old Phillip' said he was also the brother of Mosquito (Musqueto or Bush Muschetta), ${ }^{30}$ who in 1805 was captured at the Hawkesbury River and transported to Norfolk Island with Bulldog. ${ }^{31}$ Twenty years later Mosquito was hanged for murder in Hobart. ${ }^{32}$

When the Bidjigal resistance leader Pemulwuy speared Gnung-a Gnung-a in December 1795, the barbed head of the spear remained fixed in his back. The English surgeons could not remove it and considered his recovery doubtful. Gnung-a Gnung-a, however, left the hospital and walked about with the spear protruding from his back. 'At last', wrote Collins in a footnote, 'we heard that his wife, or one of his male friends, had fixed their teeth in the wood and drawn it out; after which he recovered ... His wife War-re-weer showed by an uncommon attention her great attachment to him. ${ }^{33}$

In 1802, Nicolas-Martin Petit, a young artist with the French scientific expedition commanded by Captain Nicolas Baudin, sketched a portrait of Gnung-a Gnung-a, titled Gnoung-a gnoung-a, mour-re-mour-ga (dit Collins).

Another of Bennelong's sisters, Carangarang first married Yow-war-re or Yuwarry, noted as We-ra-re in 'Names of Native Men' in the vocabulary kept by Governor Phillip and his aides (referred to here as the 'Governors' Vocabulary'). ${ }^{44}$ Yuwarry was the leading corpse bearer in the funeral of Ballooderry, a Burramattagal (man from the Parramatta clan) buried near Bennelong Point in 1791. ${ }^{35}$ Carangarang and Yuwarry had a daughter called Kah-dier-rang. The entry 'Child Boy of Yuwarry' in Daniel Southwell's vocabulary is difficult to decipher from the original handwriting, but might be interpreted as Carrangarray, who was included in 'Names of Native Men' in the 'Governors' Vocabulary', a name afterwards shortened to Krankie or Cranky. ${ }^{36}$

The French expedition's anthropologist François Péron, who used a device called a Dynamometer to test the strength of Aboriginal men in the Sydney area

29 Collins 1975[1798-1802] I: 250-251, 302-303.

30 Campbell to Lt. Gov. Davey 1814, State Records of New South Wales [hereafter SRNSW], VDL Reel 6004 4/3493: 251.

31 Sydney Gazette, 9 June, 17 July 1805.

32 Sydney Gazette, 17 March 1825.

33 Collins 1975[1798-1802] I: 371-372.

34 GV c1791: 41.13.

35 Collins 1975[1798-1802] I: 500, 502.

36 Southwell 1791, Southwell Papers, British Library, MS 16,383: 147b.3; GV c1791: 41.10. 
in 1802, listed Yuwarry as 'No. 9. Oui-roué ... Well-developed torso; thin legs, ferocious and untrustworthy aspect. ${ }^{37}$ Nothing more is heard of Yuwarry and it is presumed that he died not long afterwards.

Although 'Harry' is a likely contraction of Yuwarry, it can be shown that Carangarang's second husband, named by the Reverend Charles Wilton as 'Harry alias Corrangie', was a much younger man. ${ }^{38}$ In 1826 the Reverend Samuel Marsden wrote that: 'The Native Harry ... lived in my family, 30 years ago [1798], for a considerable time. He learned to speak our language, and while he was with me behaved well.' Harry, who Marsden hoped might become 'civilised', left to join the 'Natives in the Woods'. ${ }^{39}$

In 1816, Governor Macquarie gave Harry and Bidgee Bidgee each a suit of slop clothing, a blanket, four days provision, a half pint of spirits and a half pound of tobacco for their services as 'Native Guides' in tracking 'hostile' Aborigines in the Appin area. ${ }^{40}$ Macquarie also ordered a 'Reward of Merit' gorget to be engraved for Harry. ${ }^{41}$

Dr Joseph Paul Gaimard of the French expedition commanded by Louis De Freycinet in Sydney during 1819, examined 'Aré' (Harry), aged 32, whose pulse rate was 87 beats per minute. Gaimard also recorded the physical measurements of Harry's wife 'Karangaran' (Carangarang). ${ }^{42}$ Gaimard estimated Harry's age at 32 , giving him a birth year of 1787, making it unlikely that he could be the adult Yuwarry who officiated at Ballooderry's 1791 funeral.

Sir William Macarthur (1800-1882), in an undated Memorandum, remarked that Harry frequently visited his family home at Parramatta before he left for school in England in 1809. Macarthur recorded the warm welcome Harry gave for his father John Macarthur when he returned in 1819 from a period of exile in England. 'I remember that some strangers who were present were much astonished at Harrys eloquence, to which I have done very ill justice - they did not know he was the poet of his tribe', wrote Macarthur. ${ }^{43}$

When Harry found a pit saw at Marraymah or Charity Point (Ryde) in 1819, James Squire of Kissing Point placed a classified advertisement in the Sydney Gazette: 'If not claimed in 14 Days from this Date, it will be sold for the benefit of Black Harry. ${ }^{\prime 4}$ In 1814 Samuel Marsden had suggested Charity Point (first named Dinner Point), where the railway bridge now crosses the Parramatta River to Meadowbank, as the best place to establish a school to 'civilise' Aborigines. 'I

37 Péron 1807: 477 Table II.

38 Wilton 1828.

39 Marsden in Gunson 1974 II: 347.

40 Macquarie, 'Journal', 7 May 1816, Mitchell Library, A773.

41 Macquarie, 'Memorandum', 1816, Dixson Library, State Library of New South Wales, DL Doc 132.

42 Freycinet 2001[1839]: 111.

43 William Macarthur, undated, 'Memorandum', Mitchell Library, MS A4360, CY Reel 248: 61-67.

44 Sydney Gazette, 22 May 1819: 4. 
replied, on or near the banks of Paramatta [sic] River, opposite to the flats, as number of natives were wont to resort there at that time, for the purpose of fishing', wrote Marsden. ${ }^{45}$

In July 1822, Captain John Piper sent a petition to Governor Sir Thomas Brisbane seeking clothes and blankets from the Commissariat Store on behalf of Harry, Krankie (1st), Krankie (2nd) and others, camped near his home at Point Piper, who were 'almost in a state of nudity, suffering Cold and hunger in the extreme'. Piper wrote:

In order to supplicate your Excellency for relief They solicited a White Man to put their unfortunate situation in writing for your Excellencys humane consideration, and as your Excellency has extended your benevolence to several of their suffering brethren, they humbly hope your Excellency will allow them some sort of covering from His Majestys store. ${ }^{46}$

Krankie (1st) was another name for Harry's wife Carangarang, recorded as 'One Old Woman named Cranky', said to be 60 years of age, when she was included in the 1837 'Return of Aboriginal Natives' issue of government blankets at Brisbane Water in Broken Bay. ${ }^{47}$ Krankie (2nd) was probably the son of Carangarang and her first husband Yuwarry.

The French surgeon and pharmacist René-Primavère Lesson, who visited Sydney in 1824, named Harry as 'chef de la peuplade de Paramatta', that is, chief of the Parramatta people or clan. ${ }^{48}$ Writing in 1828, the Reverend Wilton said Harry was 'Chief of Parramatta'. ${ }^{49}$

Judge Barron Field praised Harry as 'the most courteous savage that ever bade good-morrow'.$^{50}$ When Harry gave him the words of a corroboree, Field remarked: 'I took down the following Australian national melody from Harry, who married Carangarang, the sister of the celebrated Bennilong. ${ }^{51}$ Harry, who attended the Orphan School at Parramatta, run by Anna Josepha King, wife of Governor PG King, was literate. In a letter to the editor of the Sydney Morning Herald in 1890, George Macarthur wrote:

Sir, - There was an old letter extant in 1848, which was written by an aboriginal named Harry, who was a very remarkable man, and one of the cleverest mimics to be imagined. Harry was taught to read and write in the school at Paramatta (not Parramatta as now spelled), and the letter to which I refer was addressed to my mother, who had, at its date,

45 Marsden 1822: 68.

46 John Piper, 'Petition of the Natives at Point Piper...', July 1822, SRNSW, Colonial Secretary, Reel 6052; 4/1753: 159.

47 'Return of Aboriginal Natives, Brisbane Water, 5th June 1837', SRNSW.

48 Lesson 1839[1824]: 277.

49 Wilton 1828: 233.

50 Field 1825: 438.

51 Field 1825: 433-434. 
returned with her parents to England. It commenced 'My dear Maria.' Subsequently Miss King returned to the Colony as Mrs. Hannibal McArthur, of 'the Vineyard,' now known as 'Subiaco.' Many years ago my mother showed me this letter ... ${ }^{52}$

Replying to a correspondent, George Macarthur said 'The letter itself was written in the year after Governor King had left the colony; that was in 1807.' He added: 'I knew "Harry" and his contemporary "Bidgee Bidgee" personally and intimately, for as boys we were allowed to go out with them on excursion to hunt opossums and bandicoots.' ${ }^{53}$ Harry's letter has not been traced.

While in Sydney in 1833, the Austrian scientist Baron Charles von Hügel, was shown a letter he thought was written by Bennelong, 'such as a child might write, in which he reminisced about the wife of Governor King' ${ }^{54}$ It was more likely the letter written by Harry. Anna Josepha King spent much of her time supervising the Orphan School, which became known as 'Mrs King's Orphanage'.

Dawes included Wúrrgan or Worogan (Crow) among Bennelong's sisters. ${ }^{55}$ She was probably Bennelong's half-sister by Yahuana, second wife of Bennelong's father Goorah Goorah. Worogan married Yerinibe or Yeranabie Goruey, called 'Palmer', the Burramattagal brother of Boorong and Ballooderry and halfbrother of Bidgee Bidgee, clan head for 20 years from 1816 of the Kissing Point (Ryde) 'Tribe'.

In 1801, Yeranabie and Worogan sailed with Lieutenant James Grant on the sloop Lady Nelson to Jervis Bay and on to Westernport and Churchill Island in Port Phillip. Grant wrote that Yeranabie 'spoke English tolerably well ... Worogan ... spoke English. She had always lived in the neighbourhood of Sydney'. ${ }^{56}$ Yarranabbi Road, Darling Point is named after 'Yaranabi' (Yeranabie), 'King of the Darling Point' tribe during the 1830s and 1840s, according to George Thornton. ${ }^{57}$

\section{Bennelong's wives and children}

Bennelong's first wife, whose name is not known, had died before his capture in November 1789, probably from smallpox. Soon after Bennelong escaped from Governor Phillip's house, on 3 May 1790, he resumed living with Barangaroo, who, said Collins, was 'of the tribe of Cam-mer-ray', centred at Kayeemy (Manly Cove) on the north shore of Port Jackson. ${ }^{58}$ She had two children from a previous

52 Macarthur, 'Letter to the Editor', Sydney Morning Herald, 17 July 1890.

53 Macarthur, Sydney Morning Herald, 1890 in Newspaper Cuttings, vol 51, Australian Aborigines, Mitchell Library, MLQ J72.9901/N.

54 von Hügel 1833-1834: 348.

55 Daniel Southwell, 1791, 'A List of Words...', Southwell Papers, 1787-1793, British Library, 16,383: ff147-149; 'Australian raven - wugan wo-gan', Troy 1993: 53.17.

56 James Grant, 1801, Historical Records of New South Wales, vol IV: 106-107.

57 Thornton 1892: 7.

58 Collins 1975[1798-1802] I: 463. 
husband, both of whom had died. His relationship with Barangaroo might explain Bennelong's presence at Manly Cove when he was captured in 1789 and when Phillip was speared at the whale feast in September 1790.

Bennelong's joking statement at the whale feast that Barangaroo had 'become the new wife' of Colebee and that he had replaced her with Bul-la Mur-ee Deein ('two big women') has the ring of truth. ${ }^{59}$ When Bennelong, in a boat with Phillip, met Barangaroo at Rose Bay on 3 February 1790 (before his escape), she told him that Colebee was fishing on the other side of the hill. ${ }^{60}$ Barangaroo gave birth to a baby girl named Dilboong (Bellbird), but she lived for only a few months. ${ }^{61}$ When Barangaroo died late in 1791, she, like Arabanoo and Dilboong, were buried in Governor Phillip's garden, in the present Circular Quay precinct.

After a duel with his enemy, the Gweagal elder Mety, at Botany Bay in November 1790, Bennelong had abducted Kurúbarabúla or Goroobarooboollo, a Gweagaliang about 17 years of age. ${ }^{62}$ According to Dawes, she was the ngarángaliáng or younger sister of Warungín, Wangubíle Kólbi (Botany Bay Colebee), who had exchanged names with the Cadigal leader Colebee. ${ }^{63}$ Kurúbarabúla remained with Bennelong until he and Yemmerrawanne sailed to England on HMS Atlantic with Arthur Phillip in December 1792. ${ }^{64}$ While Bennelong was in England, she became the companion of Caruey, a young Cadigal related to Colebee. ${ }^{65}$

Sometime after his return from England in 1795, Bennelong found another partner, who gave birth to a child about 1804. A'son of the memorable Bennelong' was among the children placed in the Native Institution at Parramatta during the Native Conference in 1816. ${ }^{66}$ This is the only published reference to Bennelong through all the long years of Macquarie's term as governor of New South Wales. Macquarie did not mention Bennelong in either his private journal or his Memoranda E Related Papers.

Bennelong's son Dicky was admitted to the school on 28 December 1816. He remained there until 1821, when he went to live in the house of the Wesleyan (Methodist) missionary, Reverend William Walker, who taught him to read and write and publicly baptised him Thomas Walker Coke (after Dr Coke, who

59 Tench 1793: 55.

60 Bradley 1969: 187.

61 'Dil-boong, Bennillong's infant child', Collins 1975[1798-1802] I: 490; 'A bird with a shrill noteDil-bung', GV c1791: 19.11; 'bird - a small bird with a shrill note, often heard in low wet ground and in copses - dilbung', Troy 1993: 53.21; 'The melancholy cry of the bell-bird (dil boong, after which Bennillong named his infant child)', Hunter in Collins 1975[1798-1802] II: 120 (not noted by Troy).

62 Dawes 1791: 45.6; Collins 1975[1798-1802] I: 463-464.

63 Dawes 1791: 9.1-2, 45.5 .

64 Collins 1975[1798-1802] I: 211.

65 Hunter in Collins 1975[1798-1802] II: 61.

66 Sydney Gazette, 8 December 1816. 
founded the Methodist Missions) at the Wesleyan Chapel at Parramatta on 8 September 1822. It was reported that many other Aborigines were present and that Dicky 'wept much'. ${ }^{67}$

Dicky Bennelong became ill and died early in February 1823 at the age of 19. ${ }^{68} \mathrm{He}$ had been married briefly to an Aboriginal girl named Maria, who also attended the Native School, but they had no children. Maria was the sister of Colebe or Colebee from Richmond on the Hawkesbury River. She had been brought up by the family of the Reverend Rowland Hassall and was a skilled English speaker, reader and writer. Hassall said Maria was named after Anna Maria Macarthur, daughter of Governor Philip Gidley King. ${ }^{69}$ In 1817, Maria acted as an interpreter at an inquest into the murder of an Aboriginal girl named Nanny Cabbage at Cockle Bay (Darling Harbour). The coroner, natural history artist John William Lewin, said in his report that 'a Native of the name of Maria whose knowledge of the English Language was nearly equal to his own was called in as interpreter' ${ }^{70}$

Bennelong's last wife and the woman buried with him in his grave at Kissing Point was Boorong, sister of his allies Ballooderry and Bidgee Bidgee, who told the French voyager Jules Dumont d'Urville he was the uncle of Bennelong's son. ${ }^{71}$

This picture of a rich network of kinship is based on meticulous tracking and unravelling of Indigenous names in First Fleet journals and vocabularies that makes knowable and visible many Aboriginal people otherwise lost to history while reconstructing Bennelong's family members, both before and after British settlement.

\section{After England}

Following Yemmerrawanne's death on 18 May 1794, Bennelong was anxious to return home. He boarded the 304-ton HMS Reliance at the port of Chatham on 30 July 1794, the date on a bill of one guinea for 'Post Chaise to take Mr. Benalong on board the Reliance'. ${ }^{72}$ The name 'Bannelong' appears, under 'Supernumeraries borne for Victuals only', in the ship's muster with James Williamson and Danl Paine (master shipwright Daniel Paine) on 15 September $1794 .{ }^{73}$ Four long months later, on 25 January 1795, Captain John Hunter, appointed governor of New South Wales, said he feared the 'Surviving Man (Banilong)' was so ill and

67 Sydney Gazette, 7 September 1822.

68 Coke, Thomas, Age 19, Births, Deaths and Marriages, Registrar General, Sydney, V18235654; 2B/1823.

69 Hassall, undated, 'Memorandum', Mitchell Library, Bonwick Transcripts, Box 49.

70 John William Lewin, 'Inquest on Nanny Cabbage', 14 June 1817, SRNSW, Judge Advocate Reports of Coroners Inquests, 1796-1820, AO Reel 2232: 97 et seq, Sydney.

71 Dumont d'Urville in Rosenman 1988: 85-90.

72 Treasury Board Papers, 1794, PRO: 343.

73 HMS Reliance, 1794, 'Muster', PRO 7006, ADM 36/10891. 
'broken in Spirit' that he might die. ${ }^{74}$ After further delays, the voyage began on 2 March 1795 and ended on 7 September 1795, when Reliance dropped anchor in Sydney Cove. Bennelong had been away for two years and 10 months, 18 months of which he spent on board ships, either at sea or in the docks.

The Reverend W Pascoe Crook, a newly arrived Congregational parson and missionary, stated his opinion of the Aboriginal people in a letter from Parramatta written on 5 May 1805:

The Natives of this country are more \& more Savage though Some of them have been quite Civilized they prefer wandering stark naked in the bush living on worms insects \&c this is the case with Bennelong who was in England. He visits the settlements now and then, is very polite, begs a loaf and departs. ${ }^{75}$

Crook's use of the plural 'settlements' implies that Bennelong visited Parramatta as well as Sydney.

Bennelong, wrote George Howe in the New South Wales Pocket Almanac (1818), was 'hospitably protected' by Governor King. 'The Governor frequently clothed him and he dined at the servant's table in the kitchen, at which presided Mrs. Dundas, the housekeeper, a worthy woman, and the butler, as worthy a young man.' Bennelong had dressed well and lived well in London, said Howe, 'yet upon his return to the Colony he fell off spontaneously into his early habits, and in spite of every thing that could be done to him in the order of civilization, he took to the bush, and only occasionally visited Government House'. Howe dismissed Bennelong' friendship with Governor Phillip as an 'early experiment' in European attempts to civilise the native people. ${ }^{76}$

Aboriginal people could not be swayed from their 'savage life', in the opinion of David Dickinson Mann, who left Sydney in March 1809, 'nor can the strongest allurements tempt them to exchange their wild residences in the recesses of the country, for the comforts of European life'. In The Present Picture of New South Wales, published in London in 1811, Mann cited the case of Bennelong as a 'singular instance of this fact'.

For some time after his return, it is true, he assumed the manners, the dress, and the consequence of an European, and treated his countrymen with a distance which evinced the sense he entertained of his own increased importance ... but notwithstanding so much pains had been taken for his improvement, both when separated from his countrymen, and since his return to New South Wales, he has subsequently taken to the woods again, returned to his old habits, and now lives in the same manner as those who have never mixed with the civilized world.

74 Hunter to King, 25 January 1795, PRO, C0201/12: 3.

75 Crook to Hardcastle, Parramatta, 5 May 1805, Mitchell Library, Bonwick Transcripts, Box 49: 141.

76 Howe 1818: 60. 
Sometimes, indeed, he holds intercourse with the colony; but every effort uniformly fails to draw him once again into the circle of polished society, since he prefers to taste of liberty amongst his native scenes ... ${ }^{77}$

Similar opinions about Bennelong were repeated with only slight variations in succeeding histories of New South Wales and Australia.

\section{Death and burial}

Bennelong died on 2 January 1813 at James Squire's orchard on the north shore of the Parramatta River. His obituary in the Sydney Gazette was both scathing and patronising. Professor Marcia Langton aptly described it as 'a vicious tract that failed to mention his services to the colony' ${ }^{78}$

Bennelong died on Sunday morning last at Kissing Point. Of this veteran champion of the native tribe little favourable can be said. His voyage to and benevolent treatment in Great Britain produced no change whatever in his manners and inclinations, which were naturally barbarous and ferocious.

The principal officers of Government had for many years endeavoured, by the kindest of usage, to wean him from his original habits and draw him into a relish for civilised life; but every effort was in vain exerted and for the last few years he has been but little noticed. His propensity for drunkenness was inordinate; and when in that state he was insolent, menacing and overbearing. In fact, he was a thorough savage, not to be warped from the form and character that nature gave him by all the efforts that mankind could use. ${ }^{79}$

The one dependable explanation of the cause of Bennelong's death was given in 1815 by Old Philip to ship's surgeon Joseph Arnold, who wrote in his journal: 'old Bennelong is dead, Philip told me he died after a short illness about two years ago, \& that they buried him \& his wife at Kissing point' ${ }^{80}$

While Bennelong's illness might have originated in the many wounds he had suffered over the years in the relentless cycle of payback battles, it was probably also aggravated by his 'propensity to drunkenness'. According to 'Atticus', Bennelong had been 'much addicted to spirit drinking, and for the last five months of his life was seldom sober'. ${ }^{81}$

Writing in 1883, Navy Lieutenant Richard Sadleir alleged that three Aboriginal men had been killed in a battle and several wounded, including Bennelong,

77 Mann 1811: 46-47.

78 Langton 2008: 29.

79 Sydney Gazette, 9 January 1813: 2a.

80 Arnold, 'Journal', 18 July 1815, Mitchell Library, C720: 401. In 1815 Philip and his wife settled with Bungaree and his Broken Bay people at George's Head near Mosman.

81 Sydney Gazette, 29 March 1817: 1c-2b. 
who was 'dangerously wounded and probably died'. Sadleir, who first came to Australia in 1826, relied on hearsay, as there is no extant report of a payback fight during 1813. 'Thus perished Bennillong, as a drunken savage, after all the advantages he had had of visiting England, and living at the Governor's House', concluded Sadleir. ${ }^{82}$

Bennelong was buried, with one of his wives (Boorong) in a grave in James Squire's orchard at Kissing Point beside the river that separated the Wallamattagal territory, where he lived, from that of the Wangal, his birth country. 'He [Bennelong] lies between his wife and another Chief amidst the orange trees of the garden', wrote the Reverend Charles Wilton, minister of the Parish of the Field of Mars, in the Australian Quarterly Journal. 'Bidgee Bidgee, the present representative of the Kissing Point Tribe, is a frequent visitor to these premises and expresses a wish to be buried by the side of his friend Bennelong. ${ }^{83}$ It was just 25 years - half his lifetime - since Bennelong first saw a white man.

A memorial commemorating Bennelong's burial site was erected in 1988 by the Australian Bicentennial Authority in the present Bennelong Park, by the Parramatta River (about 13 kilometres from Sydney City).

\section{Reappraisal}

After his return from England to Sydney in 1795, Bennelong was represented by contemporary observers as a flawed character: a drunk, scorned by both European and Aboriginal society. In later histories, he became the stereotype of the defeated 'native', a victim, scarred by dispossession and cultural loss, who could not adapt to European 'civilisation' ${ }^{84}$

In A History of Australia, Manning Clark asserted that 'Bennelong disgusted his civilizers and became an exile from his own people' ${ }^{85}$ Bennelong's biographer, Isadore Brodsky, said he was 'no longer wanted by his own people, and was regarded as an incorrigible savage by the whites' ${ }^{\prime}{ }^{86}$

This interpretation was reflected in Aboriginal literature, for example, the publication Aboriginal Australia, Aboriginal People of New South Wales, produced by the Aboriginal and Torres Strait Islander Commission (ATSIC) in 1997, which stated that Bennelong's long association with Phillip 'led to his being rejected by his own people'. Addressing the Council for Aboriginal Reconciliation on 27 May 2000, New South Wales Premier Bob Carr, called Bennelong 'Governor Arthur Phillip's captive, house-guest, interpreter, prize exhibit.' Carr continued: 'He died discarded by those who had used him, and rejected by his people. ${ }^{\prime 87}$

82 Sadleir 1883: 25

83 Wilton 1828: 137.

84 See the discussion by Emma Dortins in this volume.

85 Clark 1979: 145.

86 Brodsky 1973.

87 Carr, 27 May 2000. 
It is clear, however, that Bennelong, who had seen at first-hand the best and worst of European civilisation chose to reject it. In the words of John Turnbull, Bennelong

laid aside, all the ornaments and improvements he had reaped from his travels, and returned as if with increased relish, to all his former loathsome and savage habits. His clothes were thrown away as burthensome restraints on the freedom of his limbs, and he became again as compleat a New Hollander, as if he had never left his native wilds. ${ }^{88}$

It is just as certain that Bennelong returned to a respected position in the Eora clan networks from which he had taken temporary leave. Henry Waterhouse indicated as much when he wrote to Lord Sydney on 20 August 1797:

Benalong in general lives with the Governor \& occasionally takes a trip with his friends in their stile [style] \& is subject to all their Laws, \& seems to throw the Spear and wield the Club with his former dexterity. ${ }^{89}$

A series of reports in journal entries and the Sydney Gazette confirms Bennelong's leading role in ritual revenge battles around Sydney. The wounds he collected on his body in these encounters were like a map of his life. 'Bennelong is well he has been severely bruised', wrote Governor John Hunter in March 1798. ${ }^{90}$ Bennelong was greatly respected as an elder who had the power to remove teeth from boys in initiation ceremonies. He officiated at the last recorded initiation in Port Jackson, which took place in Cameragal territory 'in the middle harbour' (possibly at Georges Head) in December 1797. ${ }^{91}$

The French scientist François Péron, who tested Bennelong's strength in 1802, probably at Parramatta, estimated his age as 35-36 and noted: 'The chief; pleasing figure but somewhat thin. ${ }^{\prime 2}$

Bennelong was the leader of a 100-strong Aboriginal clan observed on the north side of the Parramatta River, west of Kissing Point, in the early years of the nineteenth century. 'General' Joseph Holt, a leader of the 1789 Irish rebellion against English rule in Wicklow, arrived in New South Wales in 1800 as a political exile. Holt managed the farms of Captain William Cox, paymaster to the New South Wales Corps. One of these was Brush Farm in the present EastwoodDundas area. Another was the Vineyard, a 140-acre property acquired by Henry Waterhouse from Phillip Schaeffer in August 1797. According to James Jervis, William Cox occupied the Vineyard during 1802-1803. ${ }^{93}$ Waterhouse's property,

88 Turnbull 1805 I: 75.

89 Waterhouse to Townshend, 20 August 1797, Thomas Townshend Papers, Dixson Library, DL MSQ 522.

90 Hunter to Chalmers, 12 March 1798, Mitchell Library, Banks Papers, A78-2: 215, Reel FM4 1747.

91 Hunter in Collins 1975[1798-1802] II: 49.

92 Péron 1807: 477 Table II.

93 Jervis 1963: 191. 
in the present Rydalmere-Dundas area, faced John Macarthur's Elizabeth Farm and was not far from James Squire's orchard at Kissing Point (Ryde), where Bennelong spent his final days.

In his Memoirs, Holt noted aspects of Aboriginal life and culture around Parramatta under governors John Hunter and Philip Gidley King. According to Holt, while fighting and hostility continued between settlers and Aborigines at the Northern Boundary (north of Parramatta), Hawkesbury River and Georges River settlements, some 50 Aborigines were camped peacefully about the Parramatta River near Clay Cliff Creek. Holt described Bennelong and his clan visiting Cox's farm. 'The king of the natives his name is Bennelong, that is to say "been long" deemed their king', he wrote. Holt bragged that he had had 'one hundred of both male and female in my yard together'. He sometimes brought the chief and his gin (wife) into his house for breakfast and a glass of grog.

I tell him to not let his people take any of my melons or corn, or, if he would, I would be murray angry with him. He say bail-that means 'never fear.' He would walk out and let out a shout, and every one of both sexes would come and get their orders, and would obey it as punctual as a soldier on his post. He hold up his hand and say Murray tat tat, pointing his hand and telling them where they were to go to make their camp, and, at the same time, he would tell them not to touch anything of Master or he would murray pialla them. Pialla is to spear them to death. All this should be done and the gin should go and get mogra [fish] for Missus. $^{94}$

In 1804 Holt was sent to Norfolk Island and later to Van Diemen's Land. He received a pardon from Governor Lachlan Macquarie and left Sydney in 1812.

Lieutenant William Lawson, in his Account of the Aborigines, said Bennelong 'died in the bush with his tribe at Kissing Point, which are all now I believe extinct'. ${ }^{95}$

The traditional ritual revenge combat fought in Sydney not long after Bennelong's death at Kissing Point was not reported in the Sydney newspapers. It was, though, witnessed by 'a free merchant of India', a passenger on the schooner Henrietta, who wrote a letter dated 'off Bass's Straits, 17th April, 1813' that was printed in the Caledonian Mercury in Edinburgh more than one year later, on 26 May 1814. The writer described the ritual, in which

the nearest relative is obliged to stand punishment ... he stands at a distance with a shield of hard wood, and the rest throw spears with great dexterity at him, while he defends himself, till wounded, or perhaps killed; and there the affair ends.

94 Holt in O'Shaunessy 1988: 68-72.

95 Lawson 1838: 554-555. 
He continued:

Lately, in the vicinity of the town [Sydney], a battle took place, where about 200 were engaged, I believe in consequence of the death of the celebrated Bennelong, who visited England some years ago, and was taken great notice of. The spears flew very thick, and about thirty men were wounded. ${ }^{96}$

When Colebee's nephew Nanbarry, a Cadigal from the eastern shore of Port Jackson, died at Kissing Point on 12 August 1821, he was buried at his own request in the same grave as Bennelong. There could be no greater mark of respect. Bidgee Bidgee, the Kissing Point (Ryde) clan head for 20 years, asked to be buried with Bennelong, but there is no record of his death or where he was buried. James Squire, who supported Nanbarry and Bennelong and was acquainted with Harry, had died in 1822. Bidgee Bidgee might be buried at Abbotsford, opposite Looking Glass Point, which was originally named Bigi Bigi. ${ }^{97}$

Bennelong's kin mourned his death. Give final consideration to the emotional testimony of the Reverend Samuel Leigh in 1821, as recounted by the Reverend Samuel Strachan.

The first tribe they met with were related to the chief Bennelong, who had died a short time before. 'I happened,' said Mr Leigh, 'to have a portrait of this celebrated chieftan, which had been taken in England, in my pocket at the time. I took it out, and showed it to them. When they looked upon his features, they were astonished, and wept aloud.' "It is Bennellong!" they cried. "He it is! Bennellong!, he was our brother and our friend!" The scene was so affecting, that Mrs. Leigh and the missionary [William Walker], who were present, mingled their tears of sympathy with the Heathen. As soon as they had recovered from their grief, we entered into conversation with them, for this tribe can speak English.' ${ }^{98}$

From his earliest negotiations with Governor Arthur Phillip, Bennelong's 'constant endeavour', in the words of Clendinnen, 'was to establish his clan, as embodied in his person, in an enduring reciprocal relationship with the British - the relationship of profitable intimacy and mutual forbearance Phillip, for a time, seemed to offer' ${ }^{99}$ This essay has demonstrated that, after his return from England in 1795, Bennelong's influence continued, through succeeding governors (even after his own death), to ensure prestige for his family and allies in the Aboriginal world and to obtain privileges from the colonial rulers. The evidence presented refutes the myth of Bennelong's pathetic demise, so commonly recited.

96 'New South Wales', Caledonian Mercury, 26 May 1814.

97 Martin 1943.

98 Strachan 1873: 147.

99 Clendinnen 2003: 272. 


\section{References}

\section{Primary sources}

Anon ['Governors' Vocabulary' (GV)] c1791, 'Vocabulary of the language of N.S. Wales in the neighbourhood of Sydney (Native and English, but not alphabetical)', School of Oriental and African Studies, University of London, London [hereafter SOAS], Notebook C, MS 41645 (c), online at <http:/ / www. williamdawes.org>

Arnold, Joseph 1815, 'Journal', Mitchell Library, Sydney, C720.

Campbell, Thomas 1814, Colonial Secretary to Lt. Gov. Davey, Van Diemen's Land, State Records of New South Wales, Sydney [hereafter SRNSW], Reel 6004; 4/3493: 251.

Crook, WP to Hardcastle, J, Parramatta, 5 May 1805, Mitchell Library, Bonwick transcripts, Box 49: 141.

Dawes, William 1790, 'Grammatical forms of the language of N.S. Wales, in the neighbourhood of Sydney, by - Dawes, in the year 1790', SOAS, Marsden Collection, Notebook A, MS 4165 (a).

- 1791, 'Vocabulary of the language of N.S. Wales in the neighbourhood of Sydney. Native and English, by - Dawes', SOAS, Marsden Collection, Notebook B, MS 4165 (b). Both Dawes vocabularies are online at <http:// www.williamdawes.org>

George III 1787, Instructions for Our Trusty and well beloved Arthur Phillip Esq. Our Captain General and Governor in Chief, in and over Our Territory of New South Wales and its Dependencies ... Given at Our Court at St. James the 25th day of April 1787, Public Record Office, London [hereafter PRO], $\mathrm{CO} 21 / 1$.

Hassall, Reverend Rowland, undated, Memorandum, Mitchell Library, Bonwick Transcripts, Box 49 .

Hunter, John to Chalmers, Mr, Sydney, 12 March 1798, Mitchell Library, Banks Papers, A78-2: 215, Reel FM4 1747.

Hunter, John to King, John, 25 January 1795, PRO, C0201/12: 3; HRNSW III: 745.

King, Philip Gidley 2006[1790], A Sydney Vocabulary 1790, An extract from the Journal of P. G. King, April 1790, State Library of New South Wales, Sydney. 
ABORIGINAL HISTORY 2009 VOL 33

Lawson, William 1838, 'Mr. Lawson's account of the Aborigines of New South Wales', SRNSW, Supreme Court Correspondence relating to Aborigines, 5/1161, Item No 82: 554-555.

Lewin, John William 1817, 'Inquest on Nanny Cabbage', 14 June 1817, SRNSW, Judge Advocate Reports of Coroners Inquests, 1796-1820, AO Reel 2232: 97 et seq.

Macarthur, William undated, Memorandum, Mitchell Library, MS A4360, CY Reel 248.

Macquarie, Lachlan, 29 December 1816, Memorandum, Dixson Library, State Library of New South Wales, Sydney, DL Doc 132.

Macquarie, Lachlan 1816, Journal, Mitchell Library, A773.

Piper, John 1822, 'Petition of the Natives at Point Piper to Governor Brisbane \&c. \&c., July 1822', SRNSW, Colonial Secretary, Reel 6052; 4/1753: 159,.

Reliance, HMS 1794, Muster, PRO 7006, ADM 36/10981.

Return of Aboriginal Natives taken at Brisbane Water on the 5th June 1837, SRNSW.

Southwell, Daniel 1791[1787-1793], Southwell Papers, British Library, London, MS 16,383: ff147-149.

Treasury Board Papers 1794, Public Record Office, London.

Waterhouse, Henry to Thomas Townshend, Sydney [HMS Reliance], 10 September 1799, Dixson Library, Thomas Townshend Papers, DL MSQ 522.

\section{Newspapers}

Caledonian Mercury, Edinburgh

Sydney Gazette

Sydney Morning Herald

The Annual Register, London

The Annual Review1802, London

The British Critic, London

The European Magazine, London

The Monthly Review, London 


\section{Secondary sources}

Aboriginal and Torres Strait Islander Commission (ATSIC), Aboriginal Australia, Aboriginal People of New South Wales; Online title 'Working with Aboriginal and Torres Strait Islanders and their communities', viewed 9 November 2009,

<http:/ /74.125.155.132/search?q=cache:vGSF4iUQby0J:www.workingwithatsi. info/content $/$ reading1D $. h t m+$ bennelong + (aboriginal $)+$ rejected $\& c d=15 \& h l=$ en\&ct $=\mathrm{clnk} \& \mathrm{gl}=\mathrm{au}>$.

Bradley, William 1969[1768-1792], A Voyage to New South Wales: The Journal of Lieutenant William Bradley RN of HMS Sirius, 1786-1792, Facs reprint, Trustees of the Public Library of NSW, Sydney.

Brook, Jack 2001, 'The forlorn hope: Bennelong and Yemmerrawannie go to England', AustralianAboriginal Studies 1: 36-47.

Carr, Bob 2000, 'Speech by Premier Bob Carr' to the Council for Aboriginal Reconciliation, Sydney, viewed 9 November 2009,

<http://www.austlii.edu.au/au/orgs/car/c2000event/speeches/Bob\%20Carr. $\mathrm{htm}>$

Clark, Manning 1979, A History of Australia, vol 1, Melbourne University Press, Melbourne.

Clendinnen, Inga 2003, Dancing with Strangers, Text Publishing, Melbourne.

Collins, David 1975[1798-1802], An Account of the English Colony in New South Wales: with remarks on the dispositions, customs, manners, Ec. of the native inhabitants of that country, to which are added, some particulars of New Zealand, 2 vols, T Cadell Jun. and W Davies, The Strand, London. Reprint, Reed in Association with the Royal Historical Society, Sydney.

Dumont d'Urville, Jules 1988[1826-9], Two Voyages to the South Seas..., Paris, Translated from the French by Helen Rosenman, Melbourne University Press, Carlton, Victoria.

Field, Barron (ed) 1825, Geographical Memoirs on New South Wales..., John Murray, London.

Freycinet, Louis de 2001[1839], Voyage autour du Monde..., translated by TB Cullity, Hordern House, Potts Point, NSW.

Grant, James 1801, 'Remarks \&c on board His Majesty's armed surveying vessel, Lady Nelson, on a voyage to explore Basses Straits', Historical Records of New South Wales 1896, vol IV, Sydney. 
Greenblatt, Stephen 1995[1991], Marvellous Possessions: The Wonder of the New World, University of Chicago Press, Chicago

[Holt, Joseph] 1988, 'Joseph Holt', in A Rum Story: The Adventures of Joseph Holt, Peter O’Shaughnessy (ed), Kangaroo Press, Kenthurst, NSW.

Howe, George 1818, 'Chronology of local occurrences', New South Wales Pocket Almanac, Sydney.

Hunter, John with A Phillip and PG King 1793, An Historical Journal of the Transactions at Port Jackson and Norfolk Island ... Including the Journals of Governors Phillip and King, and of Lieut. Ball, John Stockdale, London.

Jervis, James 1963, The Cradle City of Australia, Council of the City of Parramatta, Sydney.

Langton, Marcia 1993[1977], 'Rum, seduction and death: "Aboriginality" and alcohol', Chapter 4 in Race Matters: Indigenous Australians and 'Our' Society, Gillian Cowlishaw and Barry Morris (eds), Aboriginal Studies Press, Canberra.

- 2008, 'They made a solitude and called it peace', in First Australians: An Illustrated History, Rachel Perkins and Marcia Langton (eds), SBS/Miegunyah Press, Carlton, Victoria.

Lesson, René-Primavère 1839[1824], Voyage autour du monde ... sur la corvette La Coquille ..., Tome seconde, Paris.

Levy, M 1947, Wallumetta, Ryde Municipal Council, Ryde.

Macarthur, Geo F 1890a, Letter to the Editor, (refers to 1807 and 1848), Sydney Morning Herald, 17 July 1890.

- 1890b, Sydney Morning Herald, in Newspaper Cuttings, vol 51, Australian Aborigines, Mitchell Library, Sydney, MLQ J72.9901/N.

Mann, DD 1811, The Present Picture of New South Wales, John Booth, London.

Marsden, Samuel 1822, An answer to certain caluminies..., T Hatchard and Son, London.

[Marsden, Samuel] 1974[1826], 'Reverend Samuel Marsden's Report to Archdeacon Scott on the Aborigines of New South Wales, 2 December 1826', in Australian reminiscences E papers of L. E. Threlkeld, vol 2, Niel Gunson (ed), Australian Institute of Aboriginal Studies, Canberra.

Martin, AE 1943, One Thousand and More Place Names in New South Wales, NSW Bookstall Co Pty Ltd, Sydney. 
Péron, François and Louis Freycinet 1807, Voyage de découvertes aux Terres Australes..., Paris.

Phillip, Arthur to Lord Sydney, 13 February 1790, Historical Records of Australia, vol II: 308.

Pratt, Mary Louise 1992, Imperial Eyes: Travel Writing and Trans-culturation, Routledge, New York.

Price, GW 2000, The Minerva Journal of John Washington Price, Pamela Fulton (ed), MUP, Carlton, Victoria.

Ridley, William 1875, 'Language of George's River, Cowpasture, and Appin', in Kamilaroi, and Other Australian Languages, New South Wales Government Printer, Sydney.

Russell, Eric 1970, Lane Cove 17881985 1970, A North Shore History, Lane Cove.

Sadleir, Richard 1883, The Aborigines of Australia, Government Printer, Sydney.

Smith, Keith Vincent 2001, Bennelong: The Coming in of the Eora, Sydney Cove 1788-1792, Kangaroo Press, East Roseville, NSW.

- 2004, 'Eora Clans: A history of Indigenous social organisation in coastal Sydney, 1770-1890', unpublished MA thesis, Department of Indigenous Studies, Macquarie University, Sydney.

Stacey, AW (ed) 1981, A Basic History of Ryde 1792-1980, 3rd edn, The Ryde Historical Society, Ryde.

Strachan, Rev. Alexander 1873, Remarkable Incidents in the Life of the Rev. Samuel Leigh, Hamilton, Adams \& Co, London.

Tench, Watkin 1793, A complete account of the settlement at Port Jackson, in New South Wales, including an accurate description of the colony; of the natives; and of its natural productions..., G. Nicol and J. Sewell, London.

Thornton, George 1892, Notes on the Aborigines of New South Wales, Charles Potter, Government Printer, Sydney.

Troy, Jakelin 1993, The Sydney Language, J Troy/Australian Institute of Aboriginal and Torres Strait Islander Studies, Canberra.

Turnbull, John, 1805, A Voyage Round the World ..., vol 1, Richard Phillips, Blackfriars, London. 
ABORIGINAL HISTORY 2009 VOL 33

Von Hügel, Charles 1994[1833], New Holland Journal, November 1833 - October 1834, translated and edited by Dymphna Clark, Melbourne University Press / Miegunyah, Carlton, Victoria.

Wafer, Jim and Amanda Lissarrague 2008, A Handbook of Aboriginal Languages of New South Wales and the Australian Capital Territory, Muurrbay, Nambucca Heads.

Waterhouse, Henry 2000, The First Map of Port Jackson ..., R and L Waterhouse, Sydney.

Watts, Peter 1995, Foreword, Fleeting ENCOUNTERS, Museum of Sydney, Sydney.

Wilton, CPN (ed) 1828, The Australian Quarterly Journal of Theology, Literature and Science, A. Hill, Sydney. 